\title{
Designs for Politics in Intellectual History
}

\author{
Pollyanna Rhee
}

Department of Landscape Architecture, University of Illinois, Urbana-Champaign

${ }^{*}$ Corresponding author. E-mail: cyrhee@illinois.edu

Duncan Bell and Bernardo Zacka, eds., Political Theory and Architecture (London: Bloomsbury Academic, 2020)

Charles L. Davis II, Building Character: The Racial Politics of Modern Architectural Style (Pittsburgh: University of Pittsburgh Press, 2019)

Joy Knoblauch, The Architecture of Good Behavior: Psychology and Modern Institutional Design in Postwar America (Pittsburgh: University of Pittsburgh Press, 2020)

While working on a report on federal office space in 1962, Daniel Patrick Moynihan, then a young assistant secretary at the Department of Labor, began writing what would become the Guiding Principles for Federal Architecture and shaped the direction of the federal government's architecture for decades. ${ }^{1}$ The principles outlined two requirements for a federal building: "First, it must provide efficient and economical facilities for the use of Government agencies. Second, it must provide visual testimony to the dignity, enterprise, vigor, and stability of the American Government." Achieving those requirements demanded a willingness to follow architects' ideas, an avoidance of "an official style," and-if needed-paying "some additional cost to avoid excessive uniformity in design of Federal buildings." Citing Pericles, Moynihan argued that this pursuit would provide clear visual evidence the American government "do[es] not imitate-for we are a model to others." Over the years these principles and the subsequent Design Excellence program under the General Services Administration commissioned designs by an eclectic range of architects for federal building projects.

But in February 2020 an architecture magazine received a copy of a draft executive order titled "Making Federal Buildings Beautiful Again," officially issued in December 2020 as an Executive Order on Promoting Beautiful Federal Civic

\footnotetext{
${ }^{1}$ Guiding Principles for Federal Architecture, at www.gsa.gov/real-estate/design-construction/designexcellence/design-excellence-program/guiding-principles-for-federal-architecture, accessed 4 Oct. 2020. For context on the Guiding Principles see Lois A. Craig, The Federal Presence: Architecture, Politics, and Symbols in United States Government Buildings (Cambridge, 1978); Karen Patricia Heath, "Daniel Patrick Moynihan and His 'Guiding Principles for Federal Architecture'," PS: Political Science \& Politics 50/2 (2017), 384-7.

(C) The Author(s), 2021. Published by Cambridge University Press. This is an Open Access article, distributed under the terms of the Creative Commons Attribution licence (http://creativecommons.org/licenses/by/4.0/), which permits unrestricted re-use, distribution, and reproduction in any medium, provided the original work is properly cited.
} 
Architecture. The text proclaimed that the federal government should ensure that "the classical architectural style shall be the preferred and default style" for its buildings and rebuked those constructed under the Design Excellence program as too influenced by brutalism and deconstructivism. The nation's founders, the draft asserted, "embraced the classical models of 'democratic Athens' and 'republican Rome' for their plans for the federal capital because the style symbolized the new nation's 'self-governing ideals." Dismissing the "uninspiring," "undistinguished" buildings constructed after 1962, the draft charged that these pieces of architecture were "inconsistent with their surroundings and the architectural heritage of a region, and even just plain ugly." Federal buildings had a responsibility to "inspire the public for their aesthetics, make Americans feel proud of our public buildings, and ... respect the architectural region. Classical and traditional architectural styles have proven their ability to inspire such respect for our system of self-government." 2

Architects, architecture critics, and historians rebuked this call for classicism for its erasure of history in the name of an imagined tradition and noted the connotations of classical architecture not with democracy, but totalitarian regimes, slavery, and racism. From this perspective, classical architecture's associations spoke to a larger conflict over our political and cultural imaginations and made an implicit argument for considering architecture as more than simply, as Carl Schorske once wrote, "mere illustrative reflections of political or social developments." The tensions over meanings point to questions central to intellectual history as well as political and social thought about state priorities, the formation and representations of national cultures, and conceptions of the public and public space.

Using architecture to illustrate political and social questions is far from new. Plato's Laws and The Republic advanced the view that the design of the built environment could be mutually constitutive with ideas about political principles and institutions. Like the authors of the draft executive order, government leaders have used what the political theorists Duncan Bell and Bernardo Zacka call architectural determinism to dismiss public housing, modernist architecture, and urban designs as aesthetic and political failures. In contrast to the long history of using architecture as a central part of political theory, architectural history as a distinct field of study has a much shorter history. Architectural historians trained in doctoral programs in architecture, rather than departments of art history, began in the middle of the twentieth century. ${ }^{4}$ Scholarship in modern architecture once

\footnotetext{
${ }^{2}$ Cathleen McGuigan, "Will the White House Order New Federal Architecture to Be Classical?", Architectural Record, 4 Feb. 2020, at www.architecturalrecord.com/articles/14466-will-the-white-houseorder-new-federal-architecture-to-be-classical, accessed 5 Feb. 2021. For background on American government buildings see Craig, The Federal Presence; Charles T. Goodsell, The American Statehouse: Interpreting Democracy's Temples (Lawrence, 2001); Goodsell, "Political Meanings of the American State Capitol," Journal of Architectural and Planning Research 10/4 (1993), 294-307; Richard Longstreth, ed., The Mall in Washington, 1791-1991 (Washington, DC, 1991); John R. Parkinson, Democracy and Public Space: The Physical Sites of Democratic Performance (Oxford, 2012). For popular critiques of modernist architecture see Nathan Glazer, From a Cause to a Style: Modernist Architecture's Encounter with the American City (Princeton, 2007); Tom Wolfe, From Bauhaus to Our House (New York, 1981).

${ }^{3}$ Carl Schorske, Fin-de-Siècle Vienna (New York, 1961), xxi.

${ }^{4}$ Joan Ockman, ed., Architecture School: Three Centuries of Educating Architects in North America (Cambridge, 2012); Arindam Dutta, A Second Modernism: MIT, Architecture, and the "Techno-social" Moment (Cambridge, 2013).
} 
focused on assessments of single architects and contextualizing their work in their time. It tended to focus on stylistic shifts, architectural professionalization especially in universities, developments in national specimens of architectural modernism, and the evolution of building types. ${ }^{5}$ More recent generations of architectural historians, conversely, have expanded the scope of subject matter as well as methods. They have shown the influence of literary criticism, critical theory, history of science, and philosophy, as well as art history, as they have undertaken studies of the deployment of architectural practice within particular institutional contexts, technological and corporate imperatives, material innovations, bureaucratic regimes, socialist governments, and philosophical influences in architecture. ${ }^{6}$ In short, these histories have taken architecture seriously as a body of knowledge and practice rather than simply as a vessel to fill with political and social meanings. These works have not only put into relief the possibilities of examining context or architecture as a reflection of cultural, social, and political power; but they also demonstrate how treating architecture and urban design as an enlivening aspect of politics can inform and enrich the history of ideas. Architectural histories often bear the influence of methods and theories of other fields, such as media theory, postcolonial theory, and history of science and technology, as well as political theory. But political theorists in particular, as Bell and Zacka point out, have not always reciprocated by showing an interest in the political effects of architecture. This is curious as architecture touches on topics of state building and territorial claims, the place of monuments in society, urban renewal, science and technology, management, and forms of the state. ${ }^{7}$

\footnotetext{
${ }^{5}$ For example, see Barry Bergdoll, Léon Vaudoyer: Historicism in the Age of Industry (Cambridge, 1994); David van Zanten, The Beaux-Arts Tradition in French Architecture (Princeton, 1980); Dolores Hayden, Seven American Utopias: The Architecture of Communitarian Socialism, 1790-1975 (Cambridge, 1976); Dolores Hayden, The Grand Domestic Revolution: A History of Feminist Designs for American Homes, Neighborhoods, and Cities (Cambridge, 1981); Katherine Fischer Taylor; In the Theater of Criminal Justice: The Palais de Justice in Second Empire Paris (Princeton, 1993); Robert Fishman, Urban Utopias in the Twentieth-Century (New York, 1977).

${ }^{6}$ For example, see Mark Jarzombek, The Psychologizing of Modernity: Art, Architecture, and History (Cambridge, 2000); Arindam Dutta, The Bureaucracy of Beauty: Design in the Age of Its Global Reproducibility (London, 2006); Reinhold Martin, The Organizational Complex: Architecture, Media, and Corporate Space (Cambridge, 2003); Eeva-Liisa Pelkonen, Achtung Architecture! Image and Phantasm in Contemporary Austrian Architecture (Cambridge, 1996); Antoine Picon, French Architects and Engineers in the Age of Enlightenment (Cambridge, 1998); Claire Zimmerman, Photographic Architecture in the Twentieth Century (Minneapolis, 2014); Felicity D. Scott, Architecture or Techno-Utopia: Politics after Modernism (Cambridge, 2007); Brian McLaren, Architecture and Tourism in Italian Colonial Libya: An Ambivalent Modernism (Seattle, 2006).

${ }^{7}$ On colonial and postcolonial projects in architecture see Mark Crinson, Modern Architecture and the End of Empire (Aldershot, 2003); Ginger Nolan, The Neocolonizalism of the Global Village (Minneapolis, 2018); Hollyamber Kennedy, "Infrastructures of 'Legitimate Violence': The Prussian Settlement Commission, Internal Colonization, and the Migrant Remainder," Grey Room 76 (2019), 58-97; Jean-François Lejeune and Michelangelo Sabatino, ed., Modern Architecture and the Mediterranean: Vernacular Dialogues and Contested Identities (London, 2009); Ayala Levin, "Haile Selassie's Imperial Modernity: Expatriate Architects and the Shaping of Addis Ababa," Journal of the Society of Architectural Historians 75/4 (2016), 447-68; Sarah Lynn Lopez, The Remittance Landscape: Spaces of Migration in Rural Mexico and Urban USA (Chicago, 2015); Itohan Osayimwese, Colonialism and Modern Architecture in Germany (Pittsburgh, 2017); Will Glover, Making Lahore Modern: Constructing and Imagining a Colonial City (Minneapolis, 2008); On media and print culture see Craig Buckley,
} 
The contestation over meanings exemplified in the draft executive order calls attention to one small part of how architecture and urban design are involved in politics. Limiting the scope of the relationship between politics, political ideas, and architecture to issues of meaning and representation of national political institutions leaves out a myriad of ways the built environment works in the world. Nevertheless the conflict reveals that architecture and urban planning are not just the background or setting for politics but also shape political meanings, ideologies, and ideas. Moving away from assessments centered on architectural successes and failures or a primary focus on style makes room for new questions about how architecture and urban design contribute to the formation of public experience, assembly, and mobility. From marking out territorial boundaries to linking neighbors and neighborhoods together, attending to architecture highlights how individuals are brought together or even, going back to the question of representation, how classical styles came to be sanctioned as the appropriate style for government.

Three recent volumes-a collection of essays edited by political theorists Duncan Bell and Bernardo Zacka and monographs by Charles L. Davis II and Joy Knoblauch-put into relief the rich and manifold directions made possible by thinking about architecture as a significant aspect of understanding questions about politics and the role of the state for its population. All three books chart architecture's interactions with other fields, but also train their sights on unpacking the values ascribed to architecture and how the built environment manages a population's activities. Their approaches treat architecture as pieces of social technology and show historical connections with other fields, as well as possible methods for weaving intellectual history and architectural history together by thinking about political relationships, aesthetics, and urban form. ${ }^{8}$ By scrutinizing the meanings ascribed to buildings, as well as excavating the intellectual foundations motivating architectural design, the authors move beyond some of the pitfalls that have characterized writing about architecture, such as a tendency towards normative prescription and defining fixed, timeless meanings. Although the volumes here focus on architecture's relationship with a broad definition of politics, they also implicitly put forward new ways of thinking about intellectual history's relationship

Graphic Assembly: Montage, Media, and Experimental Architecture in the 1960s (Minneapolis, 2018); Mary Louise Lobsinger, "Architectural History: The Turn from Culture to Media," Journal of the Society of Architectural Historians 75/2 (2016), 135-9; Molly Wright Steenson, Architectural Intelligence: How Designers and Architects Created the Digital Landscape (Cambridge, 2017). On urban renewal see Otto Sumarez Smith, Boom Cities: Architect Planners and the Politics of Radical Urban Renewal in 1960s Britain (Oxford, 2019); Sam Wetherell, Foundations: How the Built Environment Made Twentieth-Century Britain (Princeton, 2020); Francesca Russello Ammon, Bulldozer: Demolition and Clearance of the Postwar Landscape (New Haven, 2016). For conceptual histories of architecture see Daniel Abramson, Obsolescence: An Architectural History (Chicago, 2016); Zeynep Celik Alexander, Kinaesthetic Knowing: Aesthetics, Epistemology, Modern Design (Chicago, 2017); Timothy Hyde, Ugliness and Judgement: On Architecture in the Public Eye (Princeton, 2019).

${ }^{8}$ Cf. G. A. Bremner and Jonathan Conlin, "History as Form: Architecture and Liberal Anglican Thought in the Writings of E. A. Freeman," Modern Intellectual History 8/2 (2011), 299-326; Chris Moffat, "Building, Dwelling, Dying: Architecture and History in Pakistan," Modern Intellectual History (2020), https://doi.org/10.1017/S1479244320000025. 
with cultural history and cultural production. As a physical form rather than a written text, architecture can present challenges to traditional understandings of intellectual history and political thought, but its study can also enliven the fields through novel questions of aesthetics, ideas of the public, or the role of space in shaping ideas.

Instead of emphasizing architectural solutions or an instrumental relationship between politics and building, Bell and Zacka see their volume as an argument for the built environment's importance and applications to a range of concerns for political theorists, from how to define community belonging and citizenship to architecture's potential to facilitate democracy. A familiar, though diverse, set of thinkers to intellectual historians, Plato, Hannah Arendt, Michel Foucault, and Henri Lefebvre-are prominent touchstones in the essays. The agora, Versailles, Brasília, and public housing each appear as locations for examining the political and social lives of citizens and rulers. The essays display a variety of approaches to "demonstrate the salience of a range of political theoretical approaches to the analysis of architecture and to show that architecture deserves a place as an object of study in political theory, alongside laws, policies, norms, practices, imaginaries, and discourses" (1). Considering architecture to be a substantive feature of political life rather than a metaphor or reflection of political institutions and ideologies raises questions, argue Bell and Zacka, about how these forms do political work (3). Contingency, informality, circumstance, mobility, and indeterminacy become central ideas and make it possible for intellectual historians to see how ideas took shape and shaped the world.

How people interact, move, and assemble, sometimes only momentarily by passing each other on the street or at greater length at a public protest or simply by sitting in a park, are fundamental issues in several of the essays. Statements about a building's intended meanings, Jan-Werner Müller acknowledges, are "bound to be political," but defining how architecture is democratic presents a thornier question, one intertwined with the "dynamics of association and dissociation" (21-2). Offering "institutionalized uncertainty" as one definition of democracy, Müller envisions architecture in this context as structures that encourage contingency by providing citizens the spaces and opportunities to make demands and commitments visible through mass gatherings (29). ${ }^{9}$

Walls between nations may seem the opposite of institutionalized uncertainty, but borderlands historians often note that borders, walls, and other physical boundaries mark out spaces for interaction, exchange, and even exceptions to rules, as much as exclusion and separation. ${ }^{10}$ At different scales, physical boundaries manifest a certain permeability leading, to unexpected results. Josiah Ober and Barry

\footnotetext{
${ }^{9}$ Cf. John R. Parkinson, Democracy and Public Space: The Physical Sites of Democratic Performance (Oxford, 2012); Craig, The Federal Presence; Charles T. Goodsell, The Social Meaning of Civic Space: Studying Political Authority through Architecture (Lawrence, 1988).

${ }^{10}$ On borderlands history see Jeremy Adelman and Stephen Aron, "From Borderlands to Borders: Empires, Nation-States, and the Peoples in between in North American History," American Historical Review 104 (1999), 814-41; Wendy Brown, Walled States, Waning Sovereignty (New York, 2010); Benjamin Johnson and Andrew R. Graybill, Bridging National Borders in North America: Transnational and Comparative Histories (Durham, NC, 2010); Anthony P. Mora, Border Dilemmas: Racial and National Uncertainties in New Mexico, 1848-1912 (Durham, NC, 2011); Samuel Truett and Pekka Hämäläinen, “On Borderlands,” Journal of American History 98/2 (2011), 338-61.
} 
Weingast combine an examination of ancient Greek sources on walled cities and their relationship to democratic processes with game theory, finding a correlation between the existence of walls, democracy, and openness to outsiders. Their conclusions express tensions between the intentions behind constructing physical boundaries and their subsequent activities. Bernardo Zacka takes up some of those tensions in his examination of apartment balconies in Beirut, which he argues serve as an "intermediary space" that encourages "reserved sociability" among relatively anonymous neighbors (83-4). For Zacka, this commonplace and seemingly minor feature of a building mediates between a home and its surroundings, transforming residential buildings into a "public in potentia" (96).

Although Bell and Zacka deemphasize prescriptive comments about how architecture should look, several of the essays impart directives with varying degrees of force. Classicist Gábor Betegh compares Magnesia, a planned city described in Plato's Laws, to modernist city planning, especially Lúcio Costa's 1957 plan for Brasília in order to ask what Magnesia "can teach us about the principles and conception motivating urban planning choices" (60). Recalling critics of modern architecture, Ronald Beiner views vernacular architecture as having a "real, culturally grounded character, as opposed to the characterless and cultureless appearance of modernist architecture at its worst" (110). He avoids arguing that buildings have moral substance baked into their designs, but also claims that modern architecture could be "as effective as the centuries-old architecture of European cities in building a civic home" if architects were "aware of the civic purposes at stake." Beiner understands architecture "as the deliberate expression of civic identity," but he leaves unanswered what a "real, culturally grounded character" of architecture would mean over time and to whom (112). Nevertheless his essay points to the need to acknowledge that political life also takes place outside the realm of high politics and formal government institutions and instead in homes, parks, streets, and neighborhoods.

This expanded scale for political life incorporates physical infrastructures that act as connective tissues facilitating mobility, communications, and exchange, including roadways, pedestrian paths, and green space. Nancy Rosenblum argues that cities function as a form of "soft power" through their dense and populous collection of people living in anonymous, yet tolerant and peaceful, coexistence (122). Residents of Queens, New York, which is often advertised as one of the most ethnically diverse places in the world, show a "live-and-let-live" obligation and moral dynamic. Duncan Bell turns to J. G. Ballard's fiction, arguing that novelists "can open up imaginative vistas, push ideas to their limits, and furnish new vocabularies to help make sense of the world," thus challenging "existing modes of apprehending, imagining, and thinking" (144). Brutalist structures celebrated in Ballard's novels of the 1970s, such as the Westway elevated highway in London, made the sensibilities of the welfare state visible in contrast to the smooth, glass forms of a later neoliberal aesthetic. At a smaller scale, Ali Aslam examines Michel Foucault's lectures on governmentality to make sense of "architecture's role in habituating subjects under conditions characterized by circulation" (169). For Foucault, urban planning created a visual framework for distinguishing between "healthy and unhealthy, safe and unsafe, orderly and disorderly parts of the city" (171). Urban parks, greenways, and routes that link segregated neighborhoods 
together hold the potential to interrupt overdetermined urban plans that privilege separation and security. Aslam calls for architects to work as a "democratic counterelite" to reframe space in order to augment "new forms of neighborliness and relationality by introducing new circuits of physical movement" (169).

Several of the essays investigate the potential of using architecture as a vital critique of capitalist development and component for encouraging urban resistance against gentrification's threats of displacing long-standing urban communities. Political theorist Margaret Kohn looks to Jane Jacobs's ideas about her adopted city of Toronto to delineate the factors that contribute to vibrancy of public life, finding that availability of affordable housing, transportation links, parks, and commercial spaces each have their role in creating a livable and just city. Short blocks, varied architectural styles, and ample opportunities for movement and connection across neighborhoods stand in contrast to "border vacuums" of uninviting and empty spaces (183). Benjamin Hofmann uses Henri Lefebvre's idea of a right to the city to argue that gentrification's offenses come not only because it expels communities, but also because it "erodes their very structure, practices, and agency" (204). The architecture critic and theorist Nathaniel Coleman advocates for "political buildings" or architecture that "contributes to intensifying tensions, or contradictions, between the empirical and the revolutionary, to reveal prospects for reconciling the two" (217). Coleman denounces what he sees as architecture's facile attempts at subversion characterized in the work of Rem Koolhaas and his Office for Metropolitan Architecture, which he sees as using ostensibly subversive tactics to highlight neoliberalism's contradictions. But ultimately he argues that their work simply reproduces the status quo. While conflicts over space and rights of inhabitation thread through several of the essays, direct political violence in its various forms, from war to the human consequences of climate change, is less of a presence. ${ }^{11}$ One exception is political theorist Mihaela Mihail's consideration of the work of architect Lebbeus Woods as political theory, seeing in architecture in the wake of political violence "the interplay between memory and imagination in collective processes of creative ... political renewal" (238).

Several of the essays highlight what the authors consider to be positive qualities of the urban built environment, but others are more directly prescriptive and address how architects should approach design. Randall Lindstrom and Jeff Malpas argue explicitly for modesty as a central concern for architecture, by which they mean conveying a feeling of boundedness (259). ${ }^{12}$ They argue for Monticello as an exemplar and the "materialization of Jefferson's politics, driven by the revolutionary spirit through which he moderated and modified his world views" (264). But their reading of the site also omits the presence of enslaved laborers who constructed the plantation, so their analysis remains partial.

\footnotetext{
${ }^{11}$ On political violence and architecture see Eyal Weizman, Hollow Land: Israel's Architecture of Occupation (New York, 2007); Samia Henni, Architecture of Counterrevolution: The French Army in Northern Algeria (Zurich, 2017); Emily Pugh, Architecture, Politics, and Identity in Divided Berlin (Pittsburgh, 2014); Lucia Allais, Designs of Destruction: The Making of Monuments in the Twentieth Century (Chicago, 2018); Felicity D. Scott, Outlaw Territories: Environments of Insecurity/Architectures of Counterinsurgency (New York, 2016).

${ }^{12}$ On modesty in architecture see Michelangelo Sabatino, Pride in Modesty: Modernist Architecture and the Vernacular Tradition in Italy (Toronto, 2010).
} 
Architectural historian Antoine Picon argues for scholars to study the relationship between sensibilities and materiality so that inquiry can shift from exploring architects' intentions to asking how architecture acts in space as a type of sensibility or as a "historically determined system of relations that both sets apart and relates" (281). In the volume's epilogue, political theorist Fonna Forman reflects on her professional career as a scholar of Adam Smith and her work with architect Teddy Cruz on the San Diego-Tijuana border. Her research in informal settlements in Tijuana built by residents using repurposed urban waste from San Diego evinces her hope that fieldwork becomes part of political theory created in partnership with local communities (305).

The numerous topics, ideas, and methods on display in Political Theory and Architecture demonstrate the protean and malleable character of both disciplines, especially when architecture is considered as more than a vessel for stable meanings or simply a reflection of political power. While leaving a broader discussion of architecture as a potential conceptual challenge to political theory mostly to the side, the essays argue for attending to specificities of place and multiple scales of analysis in political thinking within and beyond formal political institutions. These essays also underscore how questions about the relationship between architecture and politics are often questions about the meaning and representation of the state or the management of the population. Davis and Knoblauch each concentrate on one of those two concerns and they both characterize architects as intellectuals of a sort with aspirations to wide recognition and influence through their written work in addition to their designs. In focusing on the former, Davis's Building Character examines how architects deployed ideas of Western civilization and human development in their designs with the objective of delineating a culture's essential character through architecture. Seeking to reframe narratives of modern architecture's development as a historiographical intervention, Davis's book also lifts out architects' preoccupation with defining natural character in their writings and designs in order to "establish their autochthonous styles of building" (8).

Outlining a lineage for modern architecture and demonstrating stylistic progression were once long-standing concerns for architectural historians. ${ }^{13}$ For white Europeans in the nineteenth century, comparative analysis of houses across distant locales reinforced cultural hierarchies and revealed a culture's ability to move away from traditional modes of building and embrace modern ones instead. Under the influence of evolutionary theory, creating this lineage naturalized a point of view that "certain design solutions more authentically reflect the state of local culture than others" and sanctioned the use of anthropomorphic metaphors to describe stylistic developments or character (9). Using character and organicism as his explanatory frameworks, Davis aims to expose their roles as "structurally endemic to scientifically rationalized discourses of architectural style, as well as the specifically racist associations that architectural styles accrued as a result of their discrete political contexts" (8). ${ }^{14}$ What makes modern architecture modern, for Davis, is

\footnotetext{
${ }^{13}$ Cf. Hyungmin Pai, The Portfolio and the Diagram: Architecture, Discourse, and Modernity in America (Cambridge, 2002); Panayotis Tournikiotis, The Historiography of Modern Architecture (Cambridge, 1999).

${ }^{14}$ On organicism in architecture see Caroline van Eck, Organicism in Nineteenth-Century Architecture: An Inquiry into Its Theoretical and Philosophical Background (Amsterdam, 1993).
} 
its racial character, and he asks what racial, ethnic, and cultural characters were most privileged by these disciplinary debates. ${ }^{15}$

Drawing from evolutionary and developmental discourses and scholarship in ethnography, sociology, literary studies, and anthropology, Davis considers his work as an intellectual history of architecture. The result here is an architectural history that integrates scholarly sources from other fields into a dialogue with architectural history in order to cast familiar figures in a new light. This revisionist approach places less emphasis on the wider circulation and reception of racial character in architecture for a more internalist perspective. He brings the five well-known architects at the center of his study together through the concept of organicism, or the sense of the "empirical character of organic life that exhibited a wide range of representative qualities for human life," to advocate for an essentialized view of design (16). Together these architects "collectively defined architectural characters as a transparent reflection of the inner character of a national subject" across locales from the Swiss Alps to public housing in New York City. Transferring biological conceptions of race into architecture intertwined with a project of designing architectural markers of national identity.

In the first half of his book, Davis focuses on two European architects. The French architect and educator Eugène Viollet-le-Duc spent considerable time in the Swiss city of Lausanne, a place known for its preservation of medieval markettown features in the face of industrialization, to contemplate the significance of mountain ranges and vernacular Aryan culture to architecture. His 1876 book Histoire de l'habitation humaine (published in English translation in the same year as Habitations of Man in All Ages), charted a method for interpreting historical architecture inspired by contemporary writing in ethnography, philology, and geology. Taking cues from philologists who theorized the existence of a primitive Aryan language that connected European cultures together, Histoire de l'habitation humaine offered a comparative treatment of domestic architecture through allegorical illustrations that traced an evolution from Aryan huts in the form of the first chalet house at the foot of the Himalayan mountains to the Alps (36). Place, climate, and culture determined the quality of architecture and buttressed theories of societal development and civilization. The style of architecture determined where a place and its people stood on a civilizational scale.

This architectural development was not achieved solely as a natural progression. Adapting designs to suit modern needs not only evinced civilizational advancement, but also exhibited the outlines of a national aesthetic. Gottfried Semper viewed architecture as a primary means to define a unified German identity. His Four Elements of Architecture written in 1851 as a defense of Greek superiority as the source of Western civilization and democratic culture argued that a culture's ability to shift stylistically indexed its place in culture (81). In the nineteenth century, Native Americans, Chinese, and South Asians, unlike Europeans, still

\footnotetext{
${ }^{15}$ Cf. John Levi Barnard, Empires of Ruin: Black Classicism and American Imperial Culture (Oxford, 2017); Adrienne Brown, The Black Skyscraper: Architecture and the Perception of Race (Baltimore, 2017); Dell Upton, What Can and Can't Be Said: Race, Uplift, and Monument Building in the Contemporary South (New Haven, 2015); Mabel O. Wilson, Negro Building: Black Americans in the World of Fairs and Museums (Berkeley, 2012).
} 
occupied "the huts of savages," and thus showed little civilizational advancement. In the 1860s Semper railed against "the false premise that the world of architectural forms arises solely from structural and material considerations." Materials, he believed, should be subservient to social and political values associated with particular architectural forms.

The first half of Building Character emphasizes architects' writings rather than built work. In the second part, Davis crosses the Atlantic and looks closely at buildings in Chicago and New York. In Louis Sullivan's projects in Chicago, Davis observes an architecture constructed to foster "the development of national character in American citizens, while a building's style provided a visual representation of these national characteristics" (127). Regarding Sullivan's work as an assimilationist project in a time of sizable migration to Chicago, Davis argues that Sullivan's trademark botanical ornaments offered a "vernacular sign of the sociological context of the nation," meaning they represented "the significance of nature in frontier life and man's spiritual connection to his surroundings" (128).

For Davis, the varied lives of the Kehilath Anshe Ma'ariv Synagogue in Chicago's south side, designed by Sullivan in partnership with Dankmar Adler in 1889, establishes "the physical implications of Sullivan's theory of architectural physiognomy for two groups: German-speaking Jews that commissioned the structure and Black Baptist congregants who later occupied the building" (129). The synagogue's design melded aspects of traditional Jewish places of worship with those of Protestant churches, allowing the city's prosperous reform Jews to assert their cultural and social standing alongside white Protestants. In 1921 members of Pilgrim Baptist Church, a black congregation, purchased the church and began modifying the space to fit their own needs, especially for their innovative gospel choir, while maintaining some of the decorative features that signaled its life as a synagogue (155). The transition from synagogue to church, especially when considered alongside its 2006 historic preservation work, underscores debates about what designs and which individuals count as American.

Anxieties about assimilation and defining an intrinsically American character in the middle decades of the twentieth century included the place of social welfare programs, such as public housing, in the nation. Architectural modernism ascendant in Europe after World War I incorporated extensive plans for urban municipal housing, most famously in Vienna, but in the United States such programs had unattractive socialist connotations. ${ }^{16}$ When the Swiss émigré architect William Lescaze designed Williamsburg Houses in Brooklyn, at the time the most expensive design commissioned by the New York City Housing Authority, he made sure his work offered a visual contrast to the white-walled surfaces seemingly ubiquitous in European social housing. In such an approach, Davis sees Williamsburg Houses as "an instrument for shaping white working-class character during the interwar period" (176). The design combined bare concrete reminiscent of European social housing with seemingly more American brick facades, and dispensed with ornament, which Lescaze believed to be an element that weighed the nation down "with such a baroque collection of bastard buildings" (198). Proponents of modern

\footnotetext{
${ }^{16}$ Cf. Eve Blau, The Architecture of Red Vienna, 1919-1934 (Cambridge, 1999); Kimberly Elman Zarecor, Manufacturing a Socialist Modernity: Housing in Czechoslovakia, 1945-1960 (Pittsburgh, 2011).
} 
architecture argued that its rectilinear forms and reliance on up-to-date technologies rendered these structures transferable throughout the world. But Davis pushes back against the claims of universal portability and sees instead efforts to define white national character through design. Ultimately those designs stabilized ideas of racial difference and gave them physical form.

If the architects in Davis's volume used science to justify the racial hierarchies and advance a genealogy of architectural development, the Cold War-era architects in Knoblauch's volume used science as a central collaborator for articulating new forms of architecture expertise and relevance. These architects, generally lesser known than Davis's characters, participated in a different sort of modern project. Questions about meanings attached to style were replaced with those about how architecture could help manage a population's movements and attitudes through an engagement with the "soft" or behavioral sciences. ${ }^{17}$ Chronologically, Knoblauch begins in the years after Davis's conclusion and continues the inquiry into public investment in architecture in the United States. She balances two historiographical threads, architectural modernism and the mid-century ascendancy of the human sciences, to lift out how a set of behavioral scientists, urban designers, and architects, armed with government support, pursued an interdisciplinary project of designing architectural solutions to social welfare problems. In certain respects, the ambitions of these projects to improve the design of hospitals, prisons, mental-health centers, and, ultimately, the city as a whole was subordinate to the objective of molding individuals and their behaviors. Investigators asked how architectural form could be shaped to fit the psyche of a patient or prisoner and architecture served as a key tool for investigating how environmental conditions shaped and managed human behavior.

Cultivating such interdisciplinary work in "human-centered" design seemed especially consequential in the 1960s and 1970s when the United States faced critical issues of white flight, deindustrialization, and deteriorating urban cores. After the 1971 riots at Attica Prison, Ada Louise Huxtable, long-time architecture critic for the New York Times, assigned partial blame for the violence on the prison's out-of-date design. She noted that when psychologists began pursuing research in the environmental factors of behavior, they found to their surprise that architects had not yet taken up such issues (6). In certain respects these psychologists were simply following the money. Federal funding for hospitals, community mentalhealth centers, and prisons rose as direct social welfare interventions for communities waned. So these projects often acted as a "halfway, compromise measure" in the place of a robust welfare state and were undertaken by researchers and architects, bound less by shared political commitments than by a commitment to a technocratic approach to social issues (29).

\footnotetext{
${ }^{17} \mathrm{Cf}$. James Capshew, Psychologists on the March: Science, Practice, and Professional Identity in America, 1929-1969 (Cambridge, 1999); Joel Isaac, Working Knowledge: Making the Human Sciences from Parsons to Kuhn (Cambridge, 2012); Jamie Cohen-Cole, The Open Mind: Cold War Politics and the Sciences of Human Nature (Chicago, 2014); Ellen Herman; The Romance of American Psychology: Political Culture in the Age of Experts (Berkeley, 1995); Katja Guenther, Localization and Its Discontents: A Genealogy of Psychoanalysis and the Neuro Disciplines (Chicago, 2015); Michal Shapira, The War Inside: Psychoanalysis, Total War, and the Making of the Democratic Self in Postwar Britain (Cambridge, 2013).
} 
This funding provided architects with an opportunity for demonstrating their expertise, not just to their fellow designers, but to government institutions and scientific bodies. One recipient of such support, Isadore Rosenfeld, chief architect for the New York City Department of Public Works, found his services in demand far outside the city's boroughs, developing plans for health and hospital facilities in Puerto Rico and a biomedical facility for the Atomic Energy Commission (38). Under Rosenfeld's hand, architecture meant designing spaces at a modest cost for managing emotions so that staff could work calmly and efficiently and patients could find soothing relief. The aesthetic features of a hospital's architecture mattered only in as much as the "man in the street or friends and relatives of patients on approaching the hospital should not be intimidated by its officious monumentality" (38). Embracing this approach recast problems of mental health and security as technical problems with straightforward design solutions. Regional hospitals designed under the Hill-Burton Act, which provided grants and loans to communities for health care facilities, displayed modernist features with ribbon windows, breezeways, and flat roofs, but the emphasis was on technical competence and practicality instead of the design's progressive social connotations.

As considerations of reception and institutional function replaced style, the aesthetics of building types began to blur. Although some architects considered prison design unpalatable, others viewed prison design as a way to further assert the field's social relevance. The ways a prison managed a population and the way urban design managed a city's population lost some of their distinctions. When Florida experienced a rapid increase in urbanization and population in the early 1970s, the state hired Clyde Dorsett, an architect who oversaw deinstitutionalization at the National Institutes of Mental Health, to design a facility for forensic psychology in Gainesville to observe and separate its mental-health wards from its violent criminals (117). Since inconspicuous surveillance was key to this work, Dorsett's design included a series of "control rooms" to enable guards to watch inmates and sort out the population. An "open" prison designed by Middleton, Wilkerson, McMillan located in Butner, North Carolina was supposed to suggest a town center complete with shops and educational facilities linked by a colonnade (122). The prison later turned into a center for behavioral research.

Designs for facilitating surveillance and encouraging a "security state of mind" extended outside the prison and into cities and homes. Sim van der Ryn, an architect who taught at University of California, Berkeley, taught a prison design studio and imparted to his students that they could influence society through the design of institutional environments. Prefiguring broken-windows policing popularized by James Q. Wilson and George L. Kelling in the early 1980s, architect Oscar Newman and psychologist George Rand pursued research in the then developing field of environmental psychology to devise a plan of crime prevention through environmental design. Newman's 1972 book, Defensible Space, provided "a rhetorical fix to the idea that modern high-rise housing and urban design were failing" (131). In the face of perceived failures of public housing exemplified in fate of Pruitt-Igoe Apartments in St Louis and the 1964 murder of Kitty Genovese, Newman and Rand's proposals offered an affordable solution and tidy narrative about the contrasts between good and bad cities. Designers simply needed to transform cold and inhuman urban spaces into places where residents felt compelled to 
take responsibility for their property and common areas. For a federal government loath to fund welfare programs, defensible space transferred power and responsibility to individuals to monitor their environments and show themselves as healthy, normal, and secure. Research pursuits in environmental design aimed to manage a population are inextricable from the decline of the welfare state. Knoblauch's story is also one about architects' attempts to reassert social relevance and improvement in their work and articulate their body of knowledge to new urban problems. Even architects critical of their colleagues' drive toward social relevance were happy to take advantage of new sources of available funding. Nevertheless, the optimistic narratives of architecture's role in improving human behavior belied that much of this activity was the product of a "liberal establishment trying to make improvements within an accepted system using the tools they had" (119).

Like Knoblauch, several of the authors in Political Theory and Architecture focus less on canonical architects and well-known buildings, which raises questions about authorship, the significance of architectural form, and the importance of considering reception and use of spaces. How, for example, did racial ideas influence the design and construction of buildings by those outside the architectural canon? Or how can we discuss the relationship between aesthetic form and public use? All of these volumes resist the idea of architecture as a timeless or natural representation of political ideologies and evince a skepticism about any straightforward application between architecture and politics. Instead of taking surface meanings or intentions as given, the authors show how generative histories of architecture can be precisely by avoiding prescriptive assertions about how buildings should look or what they represent through lifting out historical contingencies of political applications and representations. Moreover, taking architecture and urban design seriously shows that the places where politics and history take place are not simply metaphorical. Rather than seeing ideas and institutions working under an abstract placelessness, as if all politics could occur on the head of a pin, thinking about place allows scholars to grapple with the specificity of locations as generative of ideas. Examining issues of place in political and social life offers provocations and new directions for research in intellectual history, but can also expand the scope of political thought. One striking aspect of the volumes is how little attention is paid to government buildings, including courthouses, legislatures, and city halls. Instead, hospitals, prisons, places of worship, and homes open up as places to think about political questions and ideas in practice. Intellectual historians' tools for examining the meaning and transmission of ideas are ideal for thinking about how people have designed, built, and ordered their worlds and what those results tell us. Bell and Zacka, Davis, and Knoblauch offer multiple possible directions to further pursue the link between architectural and intellectual history.

Cite this article: Rhee P (2022). Designs for Politics in Intellectual History. Modern Intellectual History 19, 958-970. https://doi.org/10.1017/S1479244321000020 